\title{
Antiasthmatic Effects of Hesperidin, a Potential Th2 Cytokine Antagonist, in a Mouse Model of Allergic Asthma
}

\author{
Seung-Hyung Kim, ${ }^{1}$ Bok-Kyu Kim, ${ }^{1}$ and Young-Cheol Lee ${ }^{2}$ \\ ${ }^{1}$ Institute of Traditional Medicine and Bioscience, Daejeon University, Daejeon 300-716, Republic of Korea \\ ${ }^{2}$ Department of Herbology, College of Oriental Medicine, Sangji University, Wonju 220-702, Republic of Korea
}

Correspondence should be addressed to Young-Cheol Lee, lyc072@sangji.ac.kr

Received 13 January 2011; Accepted 1 March 2011

Academic Editor: Steven Kunkel

Copyright (c) 2011 Seung-Hyung Kim et al. This is an open access article distributed under the Creative Commons Attribution License, which permits unrestricted use, distribution, and reproduction in any medium, provided the original work is properly cited.

\begin{abstract}
Background and Objective. The features of asthma are airway inflammation, reversible airflow obstruction, and an increased sensitivity to bronchoconstricting agents, termed airway hyperresponsiveness (AHR), excess production of Th2 cytokines, and eosinophil accumulation in the lungs. To investigate the antiasthmatic potential of hesperidin as well as the underlying mechanism involved, we studied the inhibitory effect and anti-inflammatory effect of hesperidin (HPN) on the production of Th2 cytokines, eotaxin, IL-17, -OVA-specific IgE in vivo asthma model mice. Methods. In this paper, BALB/c mice were systemically sensitized to ovalbumin (OVA) followed intratracheally, intraperitoneally, and by aerosol allergen challenges. We investigated the effect of HPN on airway hyperresponsiveness, pulmonary eosinophilic infiltration, various immune cell phenotypes, Th2 cytokine production and OVA-specific IgE production in a mouse model of asthma. Results. In BALB/c mice, we found that HPN-treated groups had suppressed eosinophil infiltration, allergic airway inflammation, and AHR, and these occurred by suppressing the production of IL-5, IL-17, and OVA-specific IgE. Conclusions. Our data suggest that the therapeutic mechanism by which HPN effectively treats asthma is based on reductions of Th2 cytokines (IL-5), eotaxin, OVA-specific IgE production, and eosinophil infiltration via inhibition of GATA-3 transcription factor.
\end{abstract}

\section{Introduction}

The features of asthma are airway inflammation, reversible airflow obstruction, and an increased sensitivity to bronchoconstricting agents, termed airway hyperresponsiveness (AHR), excess production of Th2 cytokines, and eosinophil accumulation in the lungs [1]. The immune cells involved in regulating allergic airway inflammatory responses include monocytes/macrophages, dendritic cells, neutrophils, basophils, mast cells, eosinophils, $\mathrm{T}$ and $\mathrm{B}$ lymphocytes [2]. Moreover, it is well established that there is a strong interaction between eosinophils and Th2 cells in the asthmatic airways and that Th2 cell-derived cytokines, namely IL-4, IL-5, and IL-13, play critical roles in orchestrating and amplifying allergic inflammation in asthma [3].

$\mathrm{CD} 4+\mathrm{T}$ cells play a crucial role in immune protection, and they do so through their capacity to help B cells make antibodies, to recruit neutrophils, eosinophils, and basophils to sites of inflammation, and, through their production of cytokines and chemokines, to orchestrate the immune responses [4]. Suppression of cytokine production in activated $\mathrm{CD} 4+\mathrm{T}$ cells may be useful for the treatment of asthma.

Th2 cytokines produced by CD4+ $\mathrm{T}$ cells including interleukin-4 (IL-4), IL-5, and IL-13 enhance immunoglobulin E (IgE) production, eosinophil accumulation, and IL13 directly enhances mucus hypersecretion and AHR [5, 6]. Therefore, suppression of Th2 cytokines production in activated CD4+ Th cells may be useful for the treatment of inflammatory immune diseases including asthma.

Hesperidin (HPN, 5,7,3' -trihydroxy-4' -methoxyflavanone7-rhamnoglucoside) belongs to the class of flavonoids called flavanones and is found mainly in citrus fruits and inhibits proliferation of Ramos cells and sensitizes them to 
doxorubicin-induced apoptosis through inhibition of both constitutive and doxorubicin-mediated NF- $\kappa$ B activation in a PPAR $\gamma$-independent manner [7].

Other biological activities of HPN include inhibition of cell cycle progression in human pancreatic cells [8], reduction of reactive oxygen species and triggering caspasedependent apoptosis in human polymorphonuclear neutrophils in vitro [9], cytotoxic effects on human colon cancer cells, accompanied by DNA fragmentation caspase3 activation [10], blood pressure [11], reduction of TNF$\alpha$ production [12], anti-inflammatory effects on rodent cell lines and human cell lines $[13,14]$, an antioxidant effect [15, 16], bone density loss [17], and the reduction of cholesterol [18].

However, there have been no reports of the antiasthmatic and anti-inflammatory activities of hesperidin in vivo and in vitro. The aim of this study was to evaluate the ability of HPN to control Th1- and Th2-type cytokines, various immune cell phenotypes, and other factors. Therefore, using a murine model of asthma, we studied the effect of HPN on airway eosinophil accumulation, Th2 cytokine production, various immune cell phenotypes, and histology.

\section{Materials and Methods}

2.1. Animals. Five-week-old female $\mathrm{BALB} / \mathrm{c}$ mice were obtained from Daehan Biolink Co. LTD. (Eumsung, Republic of Korea). Our study was approved by the committee for animal welfare at the institution Daejeon University. Moreover, all animal procedures were conducted in accordance with the guidelines of the Institutional Animal Care and Use Committee of the Korea Research Institute of Bioscience and Biotechnology (Daejeon, Republic of Korea).

2.2. Ovalbumin (OVA) Sensitization and Inhalation. As per the modified protocol previously described [19, 20], OVA $\left(500 \mu \mathrm{g} \mathrm{mL}^{-1}\right)$ in PBS was mixed with equal volumes of $10 \%$ (w/v) aluminum potassium sulfate (alum; Sigma) in distilled water, then incubated for $60 \mathrm{~min}$ at RT after adjustment to $\mathrm{pH} 6.5$ using $10 \mathrm{~N} \mathrm{NaOH}$, and centrifuged at $750 \times \mathrm{g}$ for 5 minutes. The OVA/alum pellet was resuspended to the original volume in distilled water. All mice were immunized on three different days (first day of 2, 3, 4 weeks before inhalational exposure) by intraperitoneal (i.p) injections of $0.2 \mathrm{~mL}$ alum-precipitated antigen containing $100 \mu \mathrm{g}$ of OVA (Sigma-Aldrich Korea, Republic of Korea) bound to $4 \mathrm{mg}$ of aluminum hydroxide (Sigma-Aldrich Korea. Republic of Korea) in PBS. Seven days after the second sensitization intratracheally injected with $250 \mu \mathrm{g}$ of OVA (on day 21) on the back of the tongue, mice were exposed to aerosolized OVA for $30 \mathrm{~min} /$ day, 3 days/week for 5 weeks (at a flow rate of $250 \mathrm{~L} / \mathrm{min}, 1 \%$ OVA in normal saline for first 4 weeks and $2 \%$ OVA in normal saline for last 1 week). HPN ( 5 and $1 \mathrm{mg} \mathrm{kg}^{-1}$, Sigma-Aldrich Korea, Republic of Korea) and formoterol $\left(1 \mathrm{mg} \mathrm{kg}^{-1}\right)$ in solution form were orally administered 3 times a week for the last 5 weeks. One day after the last OVA exposures (2\% OVA inhalation), airway hyperresponsiveness was determined and samples (bronchoalveolar lavage fluid, lung cells, and serum) were collected for further molecular analyses.

2.3. BALF (Bronchoalveolar Lavage Fluid). Immediately following assessment of AHR, mice were sacrificed with an i.p injection of sodium pentobarbitone $\left(100 \mathrm{mg} \mathrm{kg}^{-1}\right)$. The trachea was cannulated and BAL obtained by washing the airway lumina. Briefly, cells in the lungs were recovered by flushing $1 \mathrm{~mL}$ of BAL fluid (1 mM EDTA, 10\% FBS, PBS) into the lungs via the trachea. Total cell counts were determined, and $100 \mu \mathrm{L}$ of fluid was cytospun onto glass slides using a Cytospin centrifuge (Cellspin, Hanil, Republic of Korea; $400 \mathrm{~g}$ for 4 minutes). Differential cell counts were performed after staining with a Diff-Quik Stain Set (Baxter Healthcare Corp., Miami, Florida, USA). The supernatant of BALF was stored at $-25^{\circ} \mathrm{C}$ for determination of cytokine levels.

2.4. Digestion of Pulmonary Tissue and Cells Preparations. Single cell suspensions from lung tissues and BALF were isolated by mechanical disruption in RPMI 1640 medium supplemented with $2 \mathrm{mM}$ L-glutamine, $100 \mathrm{U} / \mathrm{mL}$ penicillin, $100 \mu \mathrm{g} \mathrm{mL}^{-1}$ streptomycin, $50 \mu \mathrm{M}$ 2-mercaptoethanol, $20 \mathrm{mM}$ HEPES, and 2\% heat-inactivated fetal bovine serum (FBS, GIBCO, Grand Island, NY). Briefly, the lungs were removed from thoracic cavity. After mincing using sterile scalpels, the tissue was incubated in PBS containing $1 \mathrm{mg} / \mathrm{mL}$ Collagenase IV and $2 \mathrm{mg} \mathrm{mL}^{-1}$ Dispase for $40 \mathrm{~min}$ at $37^{\circ} \mathrm{C}$ in a sterile polypropylene tube. After incubation, lung tissue was vigorously pipetted up and down to further dissolve remaining tissue clumps and then filtered using a $70 \mu \mathrm{m}$ cellstrainer (Falcon, Le Pont de Claix, France). The total number of cells was counted manually using a hemocytometer chamber (Fisher). Between 2 and $4 \times 10^{3}$ cells were spun onto glass slides (Cytospin centrifuge, Cellspin, Hanil, Korea; $400 \mathrm{~g}$ for 4 minutes). Differential counts were done according to standard morphologic criteria.

2.5. Determination of Airway Hyperresponsiveness (AHR). Airway hyperresponsiveness in mice was estimated using a previously described method with modifications [20, 21]. A Buxco system (Biosystem XA; Buxco Electronics Inc, Troy, Conn) was used to evaluate the extent of airway constriction in different groups of mice following the protocol described previously.

Penh is equal to Pause $\times$ PEF/PIF, where Pause $=(\mathrm{Te}-$ $\operatorname{Tr}$ )/ $\operatorname{Tr}$ (PIF, peak inspiratory flow; PEF: peak expiratory flow; Te, expiratory time; Tr, relaxation time). In this experiment, mice were aerosolized with OVA for $30 \mathrm{~min} /$ day, 3 days/week for 5 weeks. At 24 hours after the final inhalation, mice were given aerosolized normal saline, followed by $3.15,6.25,12.5$, 25 , and $50 \mathrm{mg} / \mathrm{mL}$ methacholine (Sigma) serially. Airway reactivity was then monitored for 30 minutes. Differences of Penh value between groups were evaluated using an unpaired Student's $t$-test.

2.6. Hematoxylin-Eosin (H\&E), Masson-Trichrome (M-T), and Periodic Acid-Schiff (PAS) Staining. BALB/c mice were injected, inhaled, and sprayed with OVA for 5 weeks (three 
times a week) to induce asthma. Two experimental groups were treated with different concentrations of HPN for the later 5 weeks ( 5 times/week). At the end of the experiment, the lungs were removed and analyzed histologically using a modified protocol previously described [22].

Briefly, the lung tissue was embedded in paraffin, then cut into $3 \mu \mathrm{m}$ thickness sections, stained with H\&E solution, M$\mathrm{T}$ solution. The tissue was subsequently mounted and coverslipped with Dako-mounting medium (Dakocytomation; Denmark Carpinteria CA). The degree of airway inflammatory cell infiltration was scored in a double-blind screen by two independent. The degree of peribronchiole and perivascular inflammation was evaluated by a subjective scale of $0-2$, as modified protocol described previously [23]. Periodic acid-Schiff (PAS) stain was performed to identify mucus secretion in lung tissue. Frozen sections $(30 \mathrm{~mm}$ in thickness) of each tissue were made. Each sample section was mounted on the gelatin-coated slide, stained with PAS reagents, dehydrated, and coverslipped with the permount. The PAS-positive goblet cells were counted manually and normalized to the length of the bronchial epithelial perimeter on the basal side, and expressed as the number of PASpositive cells per mm of basement membrane.

2.7. Antibodies and Flow Cytometric Analysis. All antibodies (such as anti-CD3, CD4, CD8, CCR3, CD69, B220, CD23, CD11b, Gr-1, etc.) for flow cytometric analysis were purchased from Becton Dickinson (BD) PharMingen (San Diego, CA). Cells from lung tissues and BALF were stained with the indicated antibodies in staining buffer (PBS containing $1 \%$ FBS and $0.01 \% \mathrm{NaN}_{3}$ ) for $10 \mathrm{~min}$ on ice, and analyzed by two-color flow cytometry on a FACSCalibur using CellQuest software (BD Biosciences, Mountain View, CA).

2.8. Enzyme-Linked Immunosorbent Assay (ELISA). Interleukin (IFN- $\gamma$, IL-4, IL-5, IL-13, IL-17, eotaxin, etc.) production in BALF and anti-OVA IgE in serum of the indicated mice $(n=5)$ was measured by ELISA according to the manufacturer's instructions with a monoclonal antibodybased mouse interleukin ELISA kit (R\&D system). OVAspecific IL-4 and IFN- $\gamma$ production from spleen cells were suspended in RPMI 1640 medium supplemented with $2 \mathrm{mM} \mathrm{L}$-glutamine, and 5\% fetal bovine serum. The spleen cells were then cultured for $48 \mathrm{hrs}$ at a concentration of $1 \times 10^{5}$ cells/well in 96-well culture plates (Corning Inc, Cambridge, Mass) with or without $1 \mathrm{ug} \mathrm{mL} \mathrm{m}^{-1}$ of OVA in a humidified atmosphere of $5 \% \mathrm{CO}_{2}$ in air at $37^{\circ} \mathrm{C}$. The culture supernatants were collected and assayed for IFN- $\gamma$ and IL-4 antibodies induced by OVA using ELISA. All data represent the mean and standard deviation from at least three separate determinants and were compared using a analysis of variance (ANOVA).

2.9. Isolation $C D 4+T$ Cells. As previously described [24], splenocytes were isolated from naive BALB/c mice. Cells were enriched for $\mathrm{CD} 4+$ cell populations by first staining the cells with anti-CD4 (BD PharMingen, Calif, USA). CD25cells were isolated from this population by first staining with fluorescein isothiocyanate- (FITC-) conjugated anti CD25 mAb (BD PharMingen) followed by incubation with magnetic-activated cell-sorting anti-FITC beads (Miltenyi Biotec, Auburn, Calif, USA). CD4+ T cells were selected on a (CS) column, and the flow-through was collected as $\mathrm{CD} 4+\mathrm{T}$ cells. Isolated cells were activated by overnight incubation on 24 -well plates coated with $1 \mu \mathrm{g} / \mathrm{mL}$ antiCD3 (Serotec.), $1 \mu \mathrm{g} / \mathrm{mL}$ anti-CD28 (Serotec.), and with HPN $(10,1 \mu \mathrm{g} / \mathrm{mL})$ added to RPMI medium supplemented with $1 \mathrm{unit} / \mathrm{mL}$ penicillin, $1 \mu \mathrm{g} / \mathrm{mL}$ streptomycin, $20 \mathrm{Mm} \mathrm{L}$ glutamine, $50 \mathrm{mM}$-mercaptoethanol, and 5\% FBS for 48 hours after stimulation.

2.10. Intracellular Staining for GATA-3 and IL-17. For GATA3 (PE mouse anti-GATA3; BD Pharmingen), IL-17 (PErat-anti-mouse IL-17; BD Pharmingen) intracellular staining, isolated $\mathrm{CD} 4+\mathrm{T}$ cells were stimulated in culture medium containing rIL-6 (100 ng/mL; R\&D Systems), TGF$\beta(20 \mathrm{ng} / \mathrm{mL}$; R\&D Systems), and monensin (GolgiStop, $1 \mathrm{~mL} / \mathrm{mL}, \mathrm{BD}$ Biosciences) in a cell incubator with $10 \% \mathrm{CO}_{2}$ at $37^{\circ} \mathrm{C}$ for $4 \mathrm{~h}$. After staining surface markers, cells were fixed and permeabilized using Cytofix/Cytoperm and Perm/Wash buffer (BD Biosciences) according to the manufacturer's instructions.

2.11. Statistical Analysis. Data were analyzed by one-way analysis of variance (ANOVA) or unpaired Student's $t$ test followed by Dunnett's multiple comparison test (SPSS version 14.0 statistic software). The difference between the normal group and the control group (OVA + vehicle) was clearly distinguished, and for this reason, statistical significance between the normal group and the control group was not shown in the figures and tables to put an emphasis on the statistical differences between the experimental groups and the control group. Results (presented as mean \pm standard error of mean) were considered statistically significant if $P$ values were $<.05(*),<.01\left(^{* *}\right)$, or $<.001(* * *)$.

\section{Results}

3.1. Inhibitory Effect of HPN on Airway Hyperresponsiveness $(A H R)$. In order to evaluate the inhibitory effect of HPN on airway hyperresponsiveness, total pulmonary airflow in mice was estimated using whole-body plethysmography. PenH was measured using a Buxco system on day 1 after final inhalation, and samples were immediately collected. Methacholine treatment is useful to exhibit the distinct effect of drugs on Penh value by way of inducing AHR. In OVAsensitized and -challenged mice, the dose-response curve of Penh value was shifted to the left compared with that of normal mice (Figure 1(b)). As shown in Figure 1(b), relative to animals sensitized with OVA (control group), AHR to methacholine was reduced in HPN-treated $\left(5 \mathrm{mg} \mathrm{kg}^{-1}\right)$ mice $(P<.01, P<.05)$ and formoterol treated mice $(P<.05)$. 


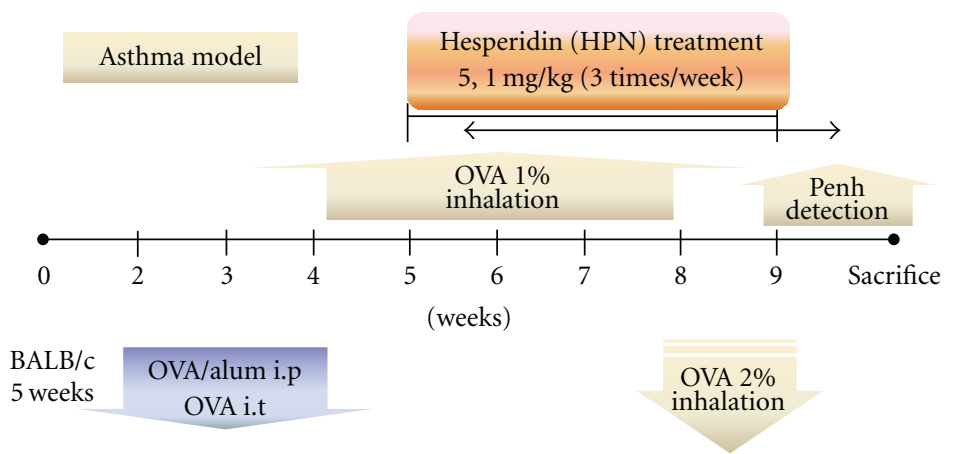

(a)
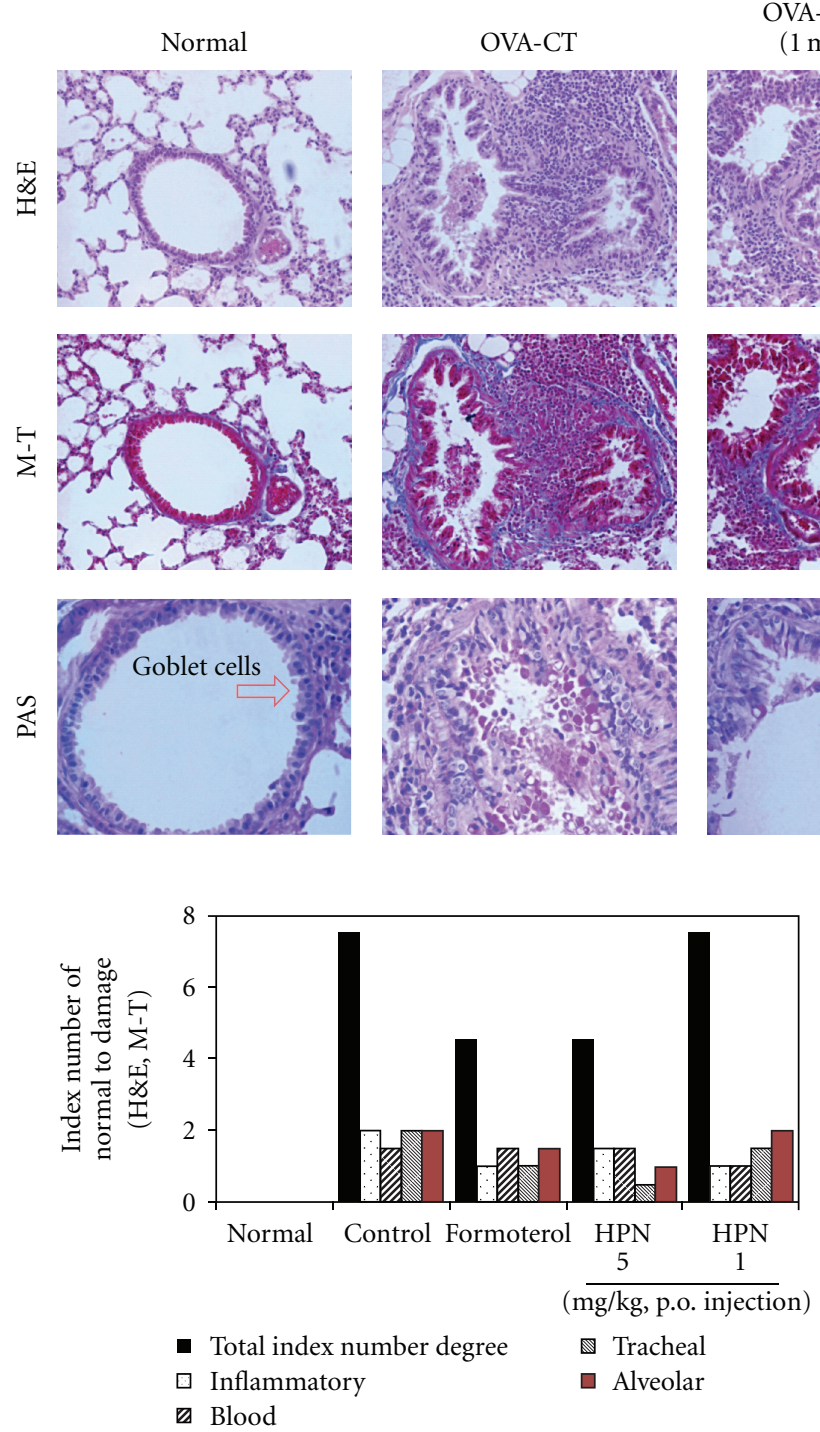

( $1 \mathrm{mg} / \mathrm{kg}$, i.p)
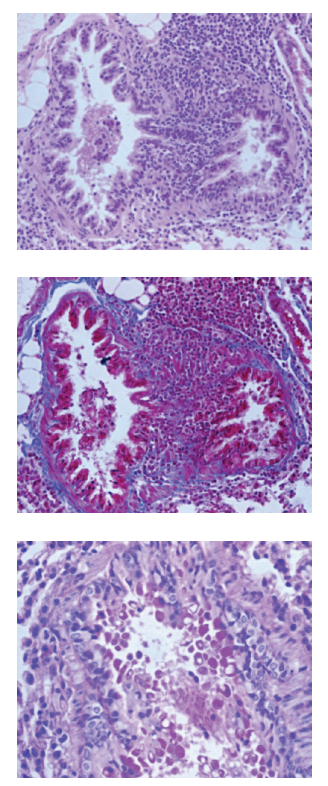

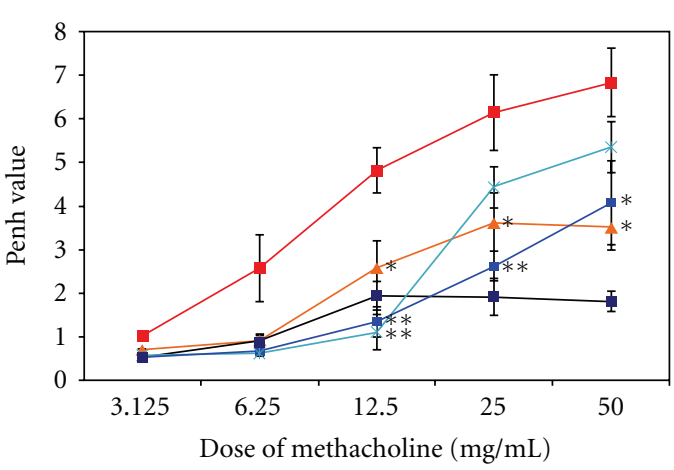

$\rightarrow-$ Normal group

$\rightarrow$ OVA-CT

- OVA-HPN $5 \mathrm{mg} / \mathrm{kg}$

ـ OVA-formoterol $1 \mathrm{mg} / \mathrm{kg}$

(b)

OVA-HPN 5

(mg/kg, p.o)
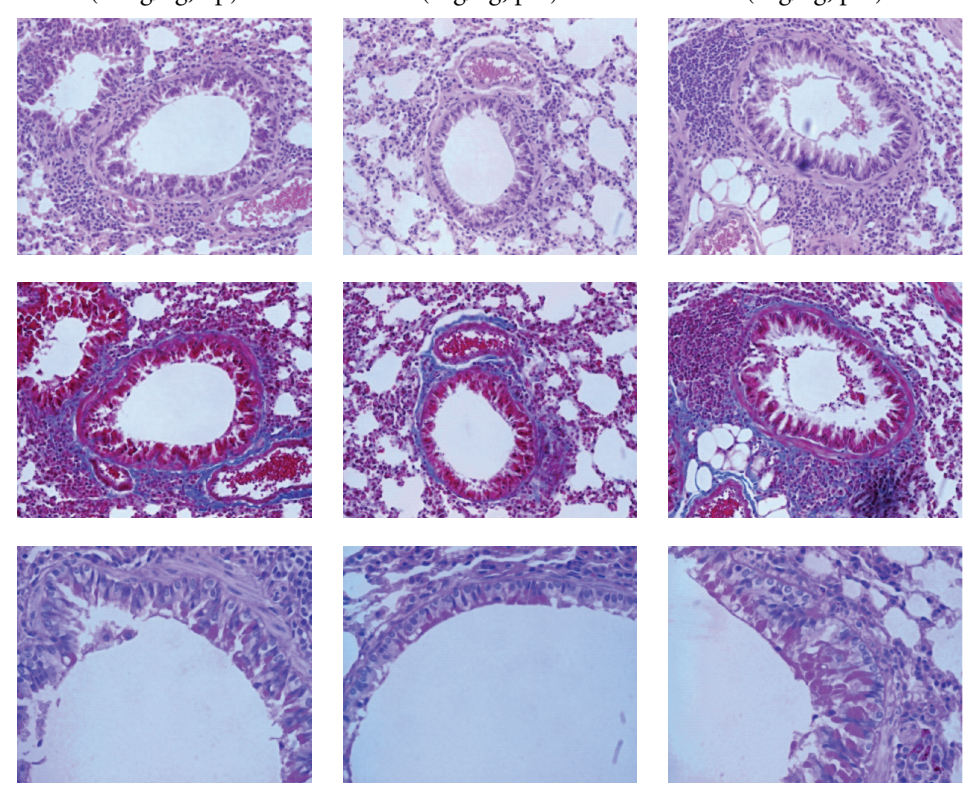

PAS-positive goblet

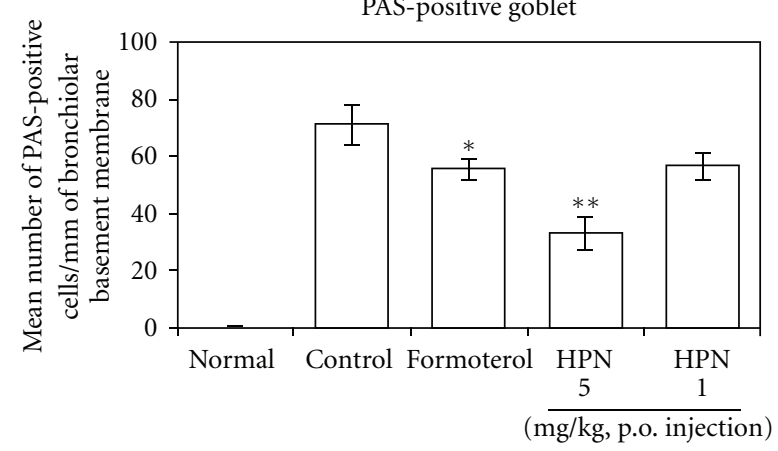

(c)

FIgURE 1: (a) Schematic diagram of methacholine-induced AHR in the sensitization protocol. (b) PenH was measured with a Buxco box, as described in Materials and Methods. ${ }^{*} P<.05,{ }^{*} P<.01$ for control goup versus HPN-treated groups (c), effect of HPN on histology of lung tissue (H\&E, M-T, and PAS staining) in lung cells of the OVA-induced murine model of asthma. H\&E: hematoxylin-eosin stain, M-T: Masson trichrome stain, PAS: Periodic acid-Schiff stain, N: normal BALB/c mice, CT (control): Ovalbumin inhalation + vehicle, OVA + formoterol (1 mg/kg), OVA + HPN (5, $1 \mathrm{mg} / \mathrm{kg})$. 
However, there was no significant difference between HPNtreated $\left(1 \mathrm{mg} \mathrm{kg}^{-1}\right)$ mice and OVA-sensitized and-challenged control mice in their methacholine-induced AHR.

3.2. Histological Analysis of Lung Sections. The histopathological investigation of both OVA-challenged mice and HPN formoterol-treated mice showed inflammatory changes when compared with saline-challenged normal mice. Also, we found infiltration of leukocytes in histologic sections of lungs from OVA-challenged control mice, and lung tissue sections from OVA-challenged mice showed a distinct inflammatory infiltrate and erosion in peribronchial and perivascular areas. The peribronchial and perivascular inflammatory infiltrate consisted of eosinophils and mast cells, admixed with lymphocytes. Eosinophil infiltration was mainly observed in the peribronchial regions of the lung. In contrast, histological sections from HPN-treated mice and formoterol-treated mice indicated reduced airway inflammation in lung tissue (Figure 1(c)).

The degrees of goblet cell hyperplasia and mucus hyperproduction were evaluated by means of PAS staining and quantification of PAS-stained cells. The OVA-challenged control mice significantly increased the mean numbers of PAS-positive cells when compared with saline-challenged normal mice.

In particular, there were greater reduction in the mean number of PAS-stained goblet cells in the HPN-treated $\left(5 \mathrm{mg} \mathrm{kg}^{-1}\right)$ and formoterol-treated asthma mice than OVAsensitized/challenged mice (Figure 1(c)).

3.3. Inhibitory Effect of HPN on Airway Eosinophil Accumulation and Influx of Inflammatory Cells into Lung and $B A L F$. The number of total leukocytes in the BALF obtained from the PBS saline challenged group was $0.95 \pm 0.05 \times 10^{7}$ cells, indicating that few eosinophils were detected in this group. On the other hand, the total number of leukocytes $\left(2.0 \pm 0.1 \times 10^{7}\right)$ and eosinophils in the BALF cytospin of the OVA-challenged was significantly higher than that in the PBS saline-challenged group.

The total number of leukocytes were significantly reduced in HPN-treated $\left(5 \mathrm{mg} \mathrm{kg}^{-1}\right)$ and formoterol-treated mice compared with control mice, and the number of total lung cells were also significantly reduced in HPN-treated mice (Figure 2(c)). HPN $\left(5 \mathrm{mg} \mathrm{kg}^{-1}\right)$ also decreased the absolute number of eosinophils in BALF (Figure 2(d)).

3.4. Inhibitory Effect of HPN on Absolute Number of Immune Cell Subtypes in Murine OVA-Induced Asthma Lung and $B A L F$. To evaluate the effect of HPN on T cell subtypes flow cytometric analysis was accomplished. The numbers of CD3, CD4, CD8, CCR3, CD69, B220, CD23, CD11b, Gr-1 positive cells in the lungs of OVA-challenged mice were increased compared to the saline-treated group, and generally, each values from HPN-treated mice were significantly lower than those of OVA-challenged mice (Table 1). Formoterol administration resulted in significant reduction in $\mathrm{T}$ cell subtypes similarly.
Effects of HPN on leukocyte subsets in lungs and BALF were marked with change in numbers of CD3+ T cells, CD4+ helper T cells, Gr-1+/CD11b+ granulocytes, CD3-/CCR3+ eosinophils, CD3+/CCR3+ Th2 cells, CD3+/CD69+ early activated T cells, B220+/CD23+ B cells in a mouse model of asthma compared to control group, and the deficits in CD3-/CCR3+ eosinophils were accompanied by concurrent decreases eosinophils in BALF cytospin (Figure 2(d)).

HPN and formoterol groups treated with OVA resulted in significant reductions in CD $3+\mathrm{T}$ cells $(* * P<.01, * * * P<$ $.001), \mathrm{Gr}-1+/ \mathrm{CD} 11 \mathrm{~b}+$ granulocytes $(* * P<.01, * * * P<$ $.001), \mathrm{B} 220+/ \mathrm{CD} 23+\mathrm{B}$ cells $\left({ }^{*} P<.05,{ }^{* *} P<.01,{ }^{*} * * P<\right.$ $.001)$ in lung were decreased significantly and CD3-/CCR3+ $\left({ }^{* *} P<.01\right), \mathrm{B} 220+/ \mathrm{CD} 23+\mathrm{B}$ cells $\left({ }^{* * *} P<.001\right)$ in BALF were also decreased significantly (Table 1$)$.

3.5. Inhibition of Th2 Cytokines (In Vivo and In vitro), Eotaxin, and OVA-Specific IgE Production in BAL Fluid and Serum. The effect of HPN and formoterol on Th2 cytokines and eotaxin protein levels was examined in BALF.

As shown in Figures 3(a) and 3(b), IL-5, IL-17, and eotaxin levels were significantly reduced in HPN-treated $\left(5 \mathrm{mg} \mathrm{kg}^{-1}\right)$ mice. An important component of allergic asthma model is the production of OVA-specific IgE. Therefore, levels of anti-OVA IgE were measured in serum from the OVA-challenged mice, PBS, formoterol- and HPNtreated groups. In our study, OVA-specific IgE levels in serum from OVA-induced asthmatic mice were significantly increased compared with normal mice (PBS only), and HPN-treated mice had significantly reduced OVA-specific IgE (Figure 3(c)). We also measured IL-4, and IFN- $\gamma$ in the culture supernatants were measured by ELISA and found that HPN (5 mg kg-1) significantly inhibited Th2 cytokine (IL-4) production in splenocytes (Figure $3(\mathrm{~d})$ ) which was accompanied by a concurrent decrease in Th2 cytokine production in BALF (Figure 3(a)).

3.6. Effect of HPN on Expression of GATA3 and IL-17 in CD4+ $T$ cells. As shown in Figure 4, the levels of CD4+/GATA3+, CD4+/IL-17+ double positive cells in CD4+ T cells were significantly increased in control group $(39.5 \%, 67.7 \%)$ stimulated with anti-CD3, anti-CD28, IL-6, and TGF- $\beta$ when compared with that of nonstimulated normal CD4+ $\mathrm{T}$ cells $(7.4 \%, 10.9 \%)$, and negative control $(7.3 \%, 12.3 \%)$. Following HPN 10, $1 \mu \mathrm{g} / \mathrm{mL}$ treatment, there was a decrease in the number of CD4+/GATA3+ T cell $(18.5 \%, 20.4 \%)$ and CD4+/IL-17+ T cell $(50.9 \%, 51.4 \%)$ when compared with that of the stimulated control group.

\section{Discussion}

Asthma is characterized by airway obstruction, which is variable and reversible, and there is chronic inflammation of the respiratory tract, which is mediated by the increased expression of multiple inflammatory proteins, including cytokines, chemokines, adhesion molecules, inflammatory enzymes, and receptors [25]. Th2 cells and their signature 


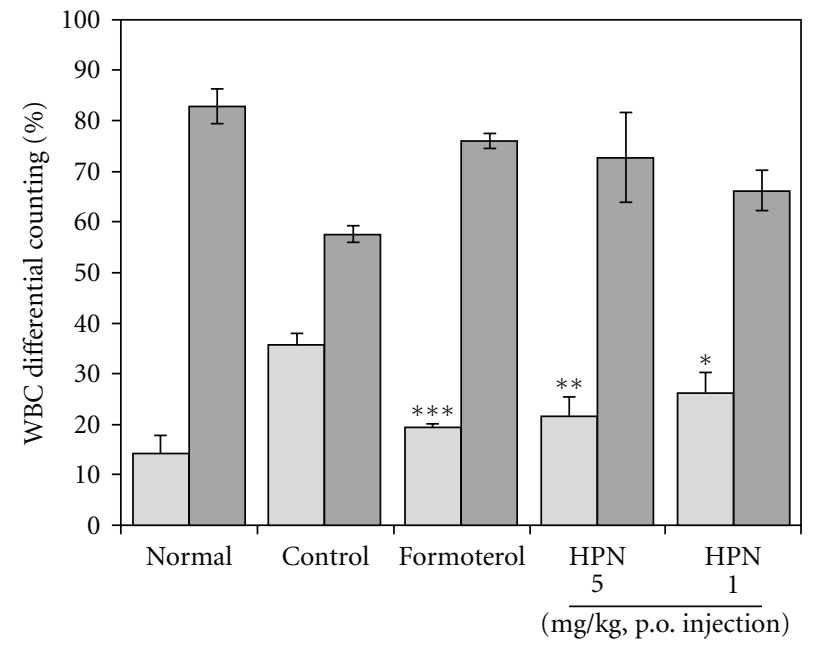

$\square$ Neutrophils in blood (WBC)

$\square$ Lymphocytes in blood (WBC)

(a)

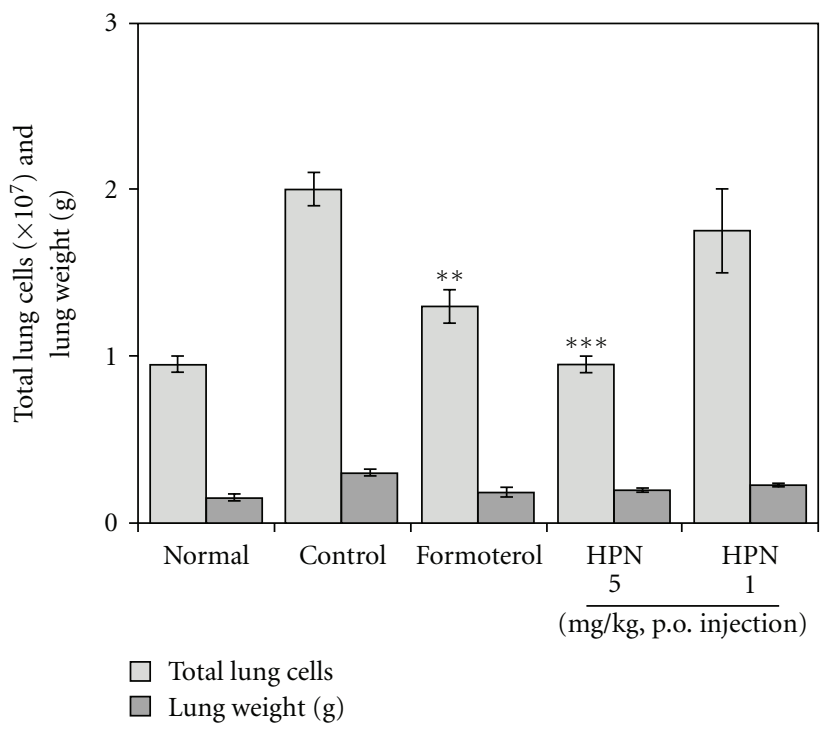

(c)

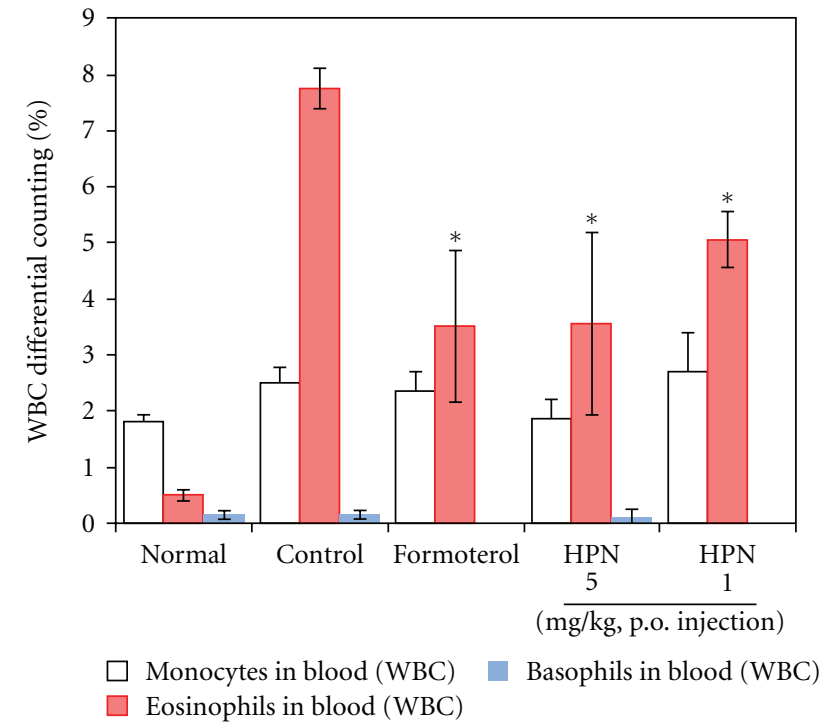

(b)

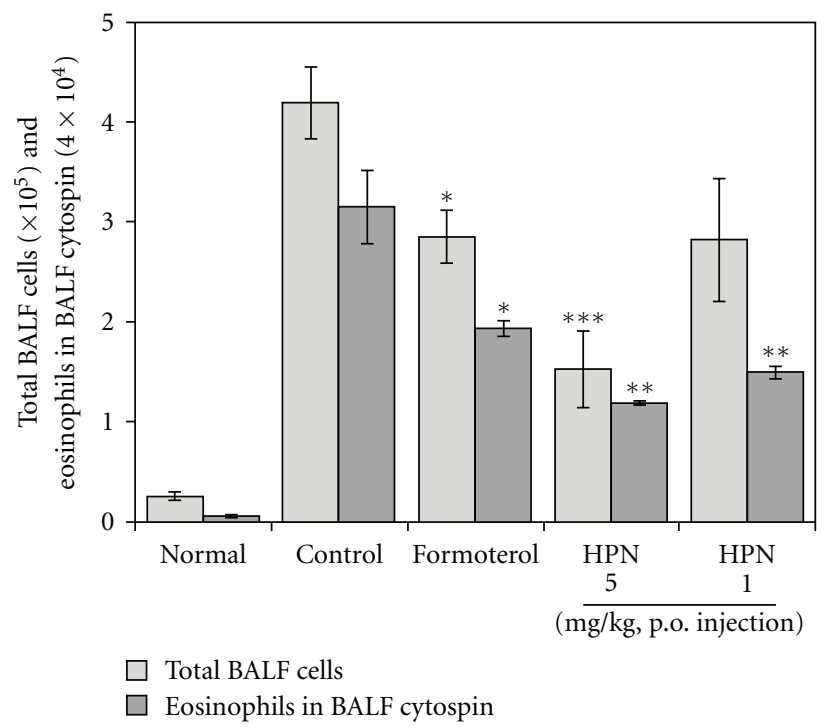

(d)

FIGURE 2: Effects of HPN on total eosinophils, neutrophils, and basophils in blood and total lung cells, total leucocytes, and eosinophils in BALF. As described in Section 2, whole blood was harvested 24 hrs after the last OVA challenge. Total inflammatory cell numbers in blood were counted, and cell classification was performed on a minimum of 200 cells to classify eosinophils and lymphocytes. Results are expressed as mean \pm S.E $(N=5)$. Statistical significance between control and treatment groups was assessed by ANOVA $\left({ }^{*} P<.05\right.$, $\left.{ }^{* *} P<.01,{ }^{* * *} P<.001\right) . N$ : normal BALB/c mice, CT: Ovalbumin inhalation+vehicle, formoterol: OVA + formoterol $(1 \mathrm{mg} / \mathrm{kg}), \mathrm{OVA}+$ $\mathrm{HPN}(5,1 \mathrm{mg} / \mathrm{kg})$.

cytokines IL-4, IL-5, and IL-13 have key pathogenic roles in asthma [26].

Therapeutic agents that may be used in the treatment of asthma are numerous. Anti-IL-5 inhibits eosinophil adhesion, infiltration, and mediator release [27]. Eosinophilia is driven by allergen-activated Th2 cells that generate large amounts of Th2 cytokines (such as IL-4, IL-5, and IL13). IL-5 is the most critical cytokine mediating increased eosinophil differentiation, activation, and survival [28]. The recruitment and activation of eosinophils appear to be controlled by the release of cytokines such as IL-5 and chemotactic agents such as eotaxin from Ag-stimulated $\mathrm{T}$ lymphocytes [29]. It has been suggested that IL-5 and eotaxin may collaborate in the regulation of blood and tissue eosinophilia in mice.

Although the exact mechanism underlying the biological efficacy of HPN remains elusive, the antiinflammatory, antioxidant, antidepressant, antimetastatic, and immunomodulatory effect were reported. However, its influence on asthma model has not been studied so far. In the previous study, it was shown that hesperidin at various dosages ranging from $0.3,5$, and $50 \mathrm{mg} / \mathrm{kg}$ body weight 


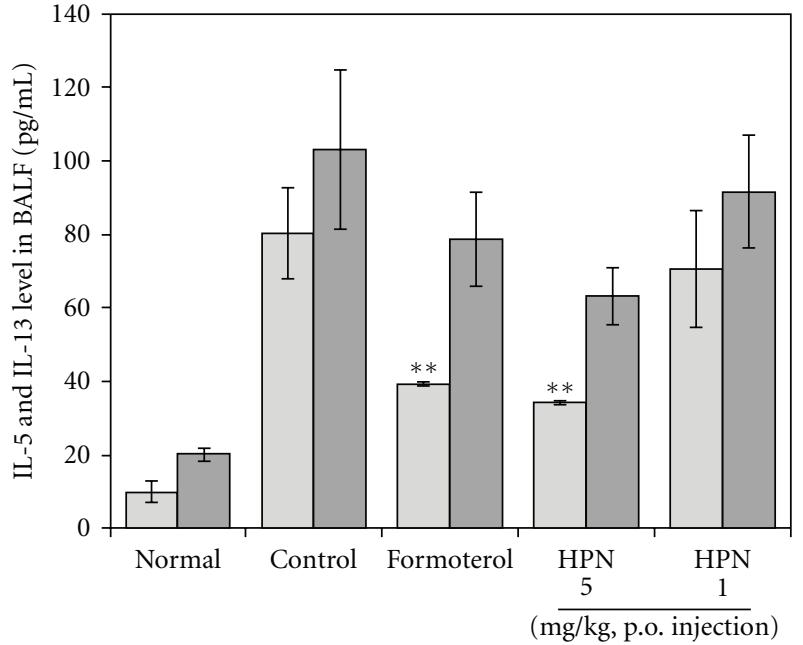

IL-5 level in BALF

IL-13 level in BALF

(a)

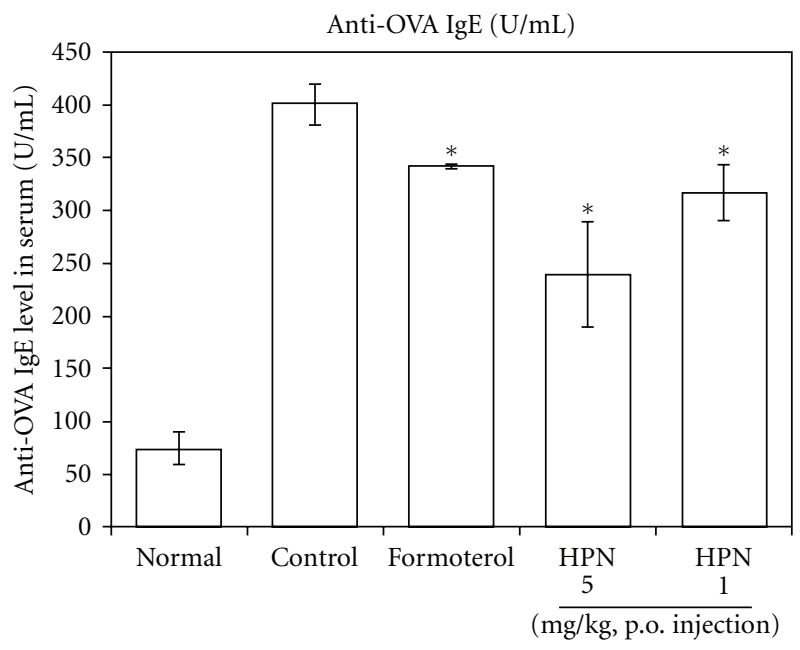

(c)

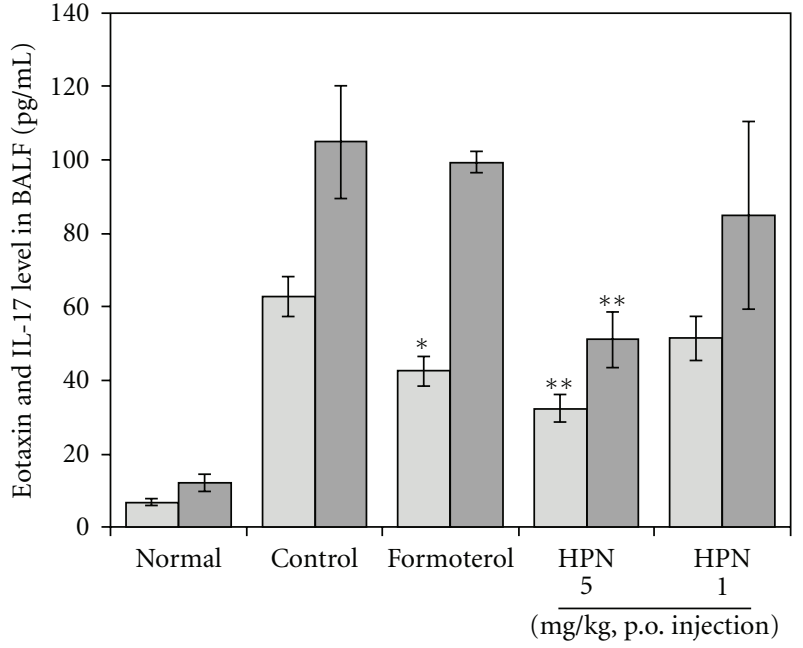

Eotaxin level in BALF

IL-17 level in BALF

(b)

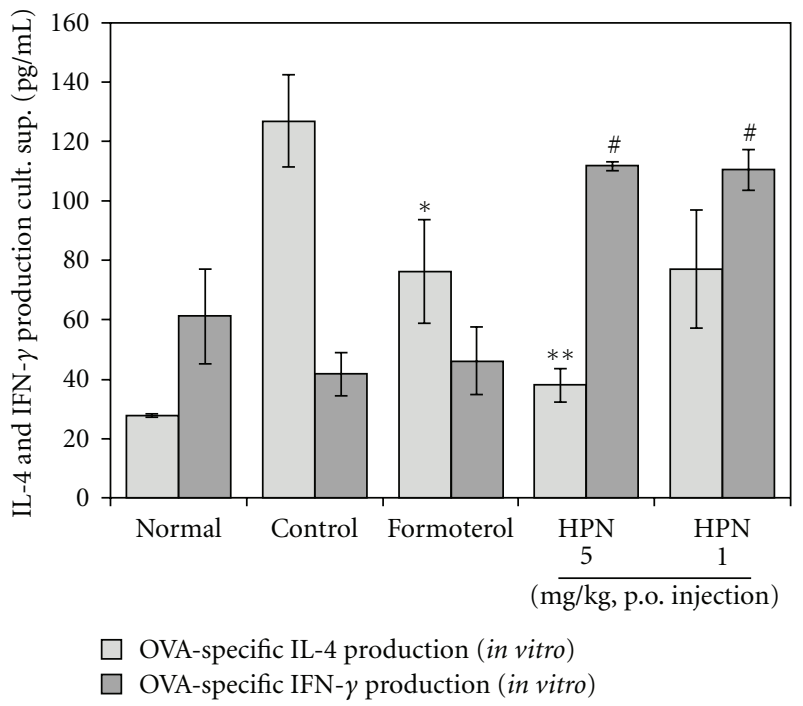

(d)

Figure 3: ((a), (b), (c)) Effect of HPN on Th2 cytokines (IL-5, IL-13), Th17 cytokine (IL-17), eotaxin in BALF, and OVA-specific IgE in serum. (d) Immunomodulatory effects of HPN on OVA-specific Th1/Th2 cytokines production in spleen cells (described in Section 2). Results are expressed the mean \pm S.E $(N=5)$. Statistical significance between control and treatment groups was assessed by ANOVA $\left({ }^{*} P<.05,{ }^{* *} P<.01\right.$, significant increase; $\left.{ }^{\#} P<.05\right) . N$ : normal BALB/c mice, CT: Ovalbumin inhalation+vehicle, formoterol: OVA + formoterol $(1 \mathrm{mg} / \mathrm{kg})$, OVA + HPN $(5,1 \mathrm{mg} / \mathrm{kg})$.

once daily by i.p injections possessed pharmacological effect [30]. Moreover, HPN attenuates LPS-induced hepatotoxicity possibly by preventing cytotoxic effects of $\mathrm{NO}$ and oxygen free radicals [31]. In our preliminary study, HPN treatment $\left(5,1 \mathrm{mgkg}^{-1}\right)$ did not cause toxic effects on alanine aminotransferase (ALT) and aspartic acid transaminase (AST) levels (data not shown). Therefore, we used the above dose for studying its effect on this model.

Formoterol, given after the allergen challenge, has a marginal inhibitory effect on the eosinophil influx and inhibits the allergen-induced airway increased airway sensitivity to aerosolized methacholine [32]. At present, for- moterol/budesonide is recommended for use as both maintenance and reliever therapy in patients with moderate to severe asthma [33]. We used it as a positive control which plays a critical role for immunosuppressants.

Recruitment of eosinophils to the airways is a characteristic of asthma, and the degree of eosinophilia is correlated with the severity of this disease. These cells are often considered to play a major role in inducing airway hyperresponsiveness (AHR) [34]. Eosinophilic inflammation is regulated to a major extent by activated $\mathrm{T}$ lymphocytes in the airways that secrete the Th2 cytokine IL-5 [35]. This cytokine is an important mediator in the regulation of eosinophilic 
TABLE 1: Quantification by means of FACS analysis of various immune cell subtypes in lung and BALF. Absolute numbers of various immune cell subtypes in lung were counted (described in Section 2). Results are expressed as mean \pm S.E $(N=5)$. Statistical significance between control and treatment groups was assessed by ANOVA $\left({ }^{*} P<.05,{ }^{* *} P<.01,{ }^{* * *} P<.001\right) . N$ : Normal BALB/c mice, CT: Ovalbumin inhalation + vehicle, formoterol: OVA + formoterol (1 mg/kg), OVA + HPN $(5,1 \mathrm{mg} / \mathrm{kg})$.

\begin{tabular}{|c|c|c|c|c|c|c|}
\hline \multirow{2}{*}{$\begin{array}{l}\text { Cell phenotypes } \\
\text { in lung and BALF }\end{array}$} & & \multirow{2}{*}{$\begin{array}{l}\text { Normal } \\
\text { BALB/c }\end{array}$} & \multicolumn{4}{|c|}{ OVA-induced asthma mice (Absolute no.) } \\
\hline & & & Control & Formoterol & $\mathrm{HPN}(5 \mathrm{mg} / \mathrm{kg})$ & HPN $(1 \mathrm{mg} / \mathrm{kg})$ \\
\hline $\mathrm{CD} 3+\left(\times 10^{5}\right.$ cells $)$ & & $3.43 \pm 0.11$ & $9.47 \pm 0.52$ & $5.08 \pm 0.37^{* * *}$ & $3.10 \pm 0.59^{* * *}$ & $6.99 \pm 0.41^{* *}$ \\
\hline $\mathrm{CD} 4+\left(\times 10^{5}\right.$ cells $)$ & & $2.03 \pm 0.07$ & $7.02 \pm 0.77$ & $3.02 \pm 0.22^{* *}$ & $2.51 \pm 0.17^{* *}$ & $5.69 \pm 0.79$ \\
\hline $\mathrm{CD} 8+\left(\times 10^{5}\right.$ cells $)$ & & $0.54 \pm 0.03$ & $1.74 \pm 0.04$ & $1.34 \pm 0.71$ & $0.64 \pm 0.04^{* * *}$ & $1.53 \pm 0.07$ \\
\hline Gr $-1+/ \mathrm{CD} 11 \mathrm{~b}+\left(\times 10^{5}\right.$ cells $)$ & & $1.45 \pm 0.01$ & $4.79 \pm 0.38$ & $2.07 \pm 0.19^{* *}$ & $1.25 \pm 0.07^{* * *}$ & $2.01 \pm 0.27^{* *}$ \\
\hline $\mathrm{CD} 3-/ \mathrm{CCR} 3+\left(\times 10^{5}\right.$ cells $)$ & Lung & $0.47 \pm 0.09$ & $4.49 \pm 1.01$ & $2.58 \pm 0.22$ & $1.92 \pm 0.13^{*}$ & $3.01 \pm 0.25$ \\
\hline $\mathrm{CD} 3+/ \mathrm{CCR} 3+\left(\times 10^{5}\right.$ cells $)$ & & $0.17 \pm 0.04$ & $1.74 \pm 0.10$ & $1.19 \pm 0.35$ & $0.91 \pm 0.15^{* *}$ & $1.44 \pm 0.04^{*}$ \\
\hline $\mathrm{CD} 3+/ \mathrm{CD} 69+\left(\times 10^{5}\right.$ cells $)$ & & $0.48 \pm 0.01$ & $3.68 \pm 0.78$ & $1.27 \pm 0.13^{*}$ & $1.42 \pm 0.12^{*}$ & $2.40 \pm 0.82$ \\
\hline $\mathrm{CD} 3-/ \mathrm{CD} 19+\left(\times 10^{5}\right.$ cells $)$ & & $1.08 \pm 0.03$ & $2.89 \pm 0.01$ & $1.66 \pm 0.13^{* * *}$ & $1.23 \pm 0.21^{* * *}$ & $2.37 \pm 0.29$ \\
\hline $\mathrm{B} 220+/ \mathrm{CD} 13+\left(\times 10^{5}\right.$ cells $)$ & & $0.21 \pm 0.07$ & $1.76 \pm 0.03$ & $0.88 \pm 0.15^{* *}$ & $0.42 \pm 0.03^{* * *}$ & $0.95 \pm 0.26^{*}$ \\
\hline $\mathrm{CD} 3+\left(\times 10^{3}\right.$ cells $)$ & & $0.44 \pm 0.11$ & $23.94 \pm 0.82$ & $10.72 \pm 0.60^{* *}$ & $6.88 \pm 1.55^{* *}$ & $13.40 \pm 4.80$ \\
\hline $\mathrm{CD} 4+\left(\times 10^{3}\right.$ cells $)$ & & $0.43 \pm 0.03$ & $21.23 \pm 1.57$ & $9.57 \pm 0.78^{* *}$ & $7.92 \pm 1.65^{* *}$ & $15.69 \pm 6.08$ \\
\hline CD8+ $\left(\times 10^{3}\right.$ cells $)$ & & $0.06 \pm 0.03$ & $2.92 \pm 0.60$ & $2.35 \pm 0.61$ & $0.85 \pm 0.40$ & $1.96 \pm 0.53$ \\
\hline CD3-/CCR3 $+\left(\times 10^{3}\right.$ cells $)$ & BALF & $0.03 \pm 0.02$ & $5.75 \pm 1.14$ & $1.62 \pm 0.01^{* *}$ & $0.53 \pm 0.11^{* *}$ & $1.14 \pm 0.16^{* *}$ \\
\hline $\mathrm{CD} 3+/ \mathrm{CCR} 3+\left(\times 10^{3}\right.$ cells $)$ & & $0.04 \pm 0.01$ & $10.79 \pm 1.15$ & $5.18 \pm 0.44^{* *}$ & $2.11 \pm 0.87^{* *}$ & $6.34 \pm 1.45$ \\
\hline $\mathrm{B} 220+/ \mathrm{CD} 23+\left(\times 10^{3}\right.$ cells $)$ & & $0.12 \pm 0.01$ & $6.64 \pm 0.15$ & $2.65 \pm 0.51^{* * *}$ & $0.94 \pm 0.32^{* * *}$ & $1.43 \pm 0.41^{* * *}$ \\
\hline
\end{tabular}

inflammation through effects on the proliferation, differentiation, and activation of eosinophils, as well as providing a signal for the rapid mobilization of eosinophils from the bone marrow [36].

HPN prevented the development of AHR (Figure 1(b)), airway eosinophilia (Table 1), lung inflammation (Figure 1(c)), and decreased Th2 cytokine levels (Figure 3(a)) in BAL fluid. These results demonstrate that HPN has profound regulatory effects on the development of lung allergic responses in the OVA-induced asthma model. Moreover, the regulatory effects exhibited by HPN were accompanied by the production of IL-4 in vitro assay (Figure 3(d)).

Asthma produces immune abnormalities in a wide variety of cell populations. Thus, another goal in asthma research includes the evaluation of specific cell subpopulations. Immunophenotyping by flow cytometry showed a similar pattern as total lymphocyte numbers in BALF and lung.

As previously described in results, effects of HPN on leukocyte subsets in lungs and BALF were marked with change in numbers of $\mathrm{CD} 3+\mathrm{T}$ cells, $\mathrm{CD} 4+$ helper $\mathrm{T}$ cells, Gr-1+/CD11b+ granulocytes, CD3-/CCR3+ eosinophils, CD3+/CCR3+ Th2 cells, CD3+/CD69+ early activated T cells, and B220+/CD23+ B cells in a mouse model of asthma compared to control group (Table 1), and the deficits in CD3-/CCR3+ eosinophils were accompanied by concurrent decreases eosinophils in BALF cytospin (Figure 2(d)). HPN also inhibits B cell-dependent production of OVA-specific IgE in serum (Figure 3(c)), which is correlated with the result of B220+/CD23+ B cells in lung and BALF.

It was recently suggested that a transient activationinduced CD69 surface expression may be important for regulating $\mathrm{T}$ cell trafficking [37]. Moreover, CD69 might affect the immune response during T-cell differentiation, involving immunoregulatory cytokines that include, but might not be limited to, TGF- $\beta$, which controls T-cell differentiation [22].

CC chemokine receptor 3 (CCR3) is expressed on eosinophils, MC, basophils, and a subset of human Th2like T lymphocytes [38]. Eosinophils are attracted, via their CCR3, in response to chemoattractants such as eotaxin released in the airways of asthmatics [39]. Inhibition of pulmonary eosinophilia by blocking the CCR3 receptor with antagonists may lead to a reduction in the inflammation and the airway responsiveness in asthma. This approach is investigated by numeral research groups.

Moreover, eosinophils are one of the cell types known to express Gr-1, therefore eosinophil populations may constitute a substantial portion of the $\mathrm{CD} 11 \mathrm{~b}+\mathrm{Gr}-1+$ populations. Our results (Table 1) showed that Gr-1+ cells were increased with OVA challenge but significantly decreased with HPNtreated mice.

Eotaxin is a potent and specific eosinophil chemoattractant [40] that also activates eosinophils, increasing both leukotriene $\mathrm{C} 4$ synthesis and eosinophil peroxidase activity [41]. Eotaxin seems to be most important in the early phases of eosinophil recruitment after allergen challenge [42]. Eotaxin has been previously implicated in allergen-induced AHR [43]. However, the relationship between eotaxin and AHR is complex. In many cases, eotaxin caused substantial airway eosinophilia and in conjunction with IL-5 caused an even more marked increase in eosinophils.

We observed significant correlations between eotaxin, IL-5 levels, and CCR3 expression on eosinophils. We 


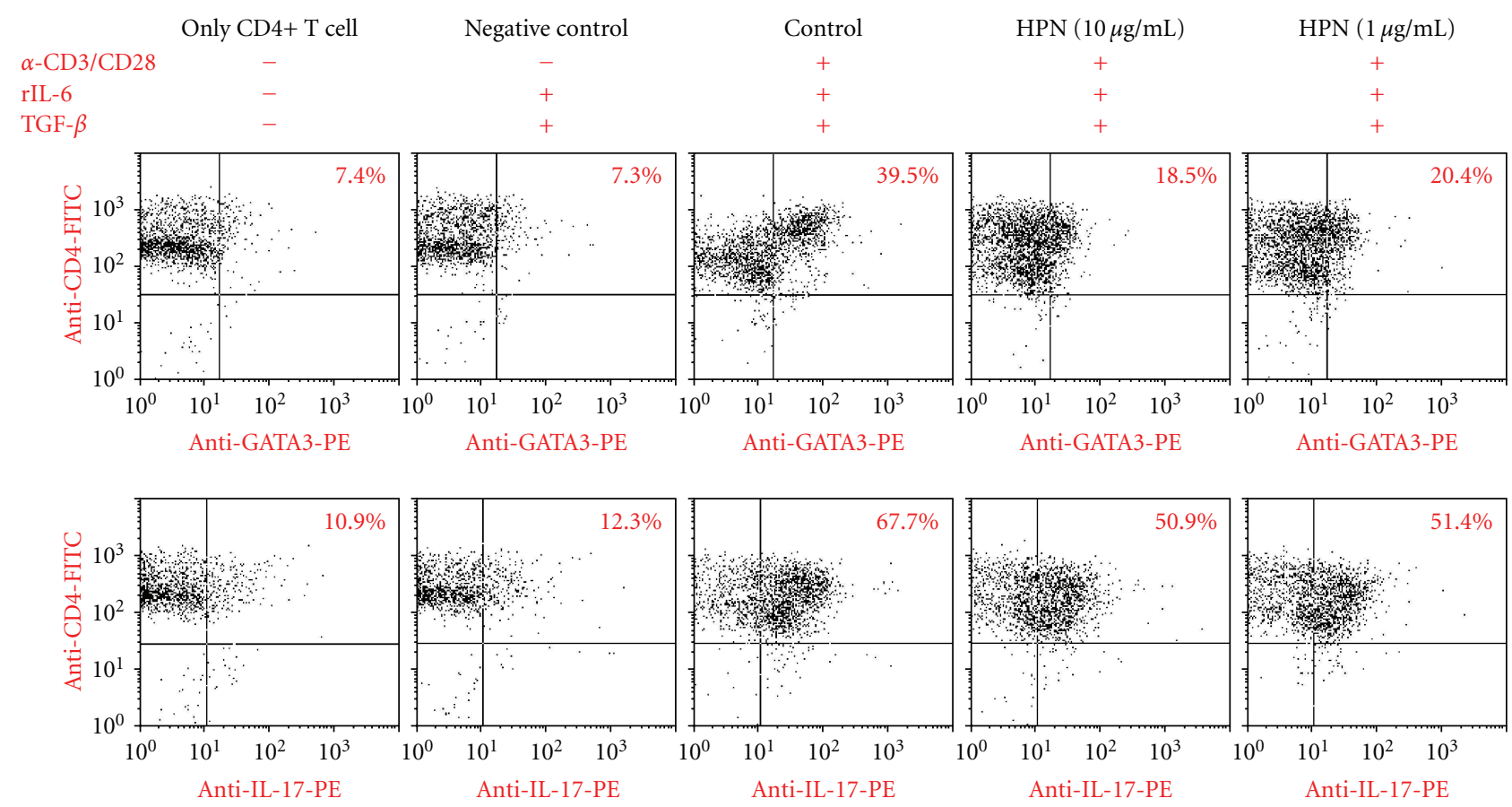

FIGURE 4: Dot plot pattern of intracellular cytokine staining. $X$-axis: PE intensity of GATA-3 and IL-17. $Y$-axis: FITC intensity of CD4. Isolated CD4+ T cells were cultured without (normal group) or with (stimulated group) anti-CD3, anti-CD28, rIL-6, TGF-beta, and with HPN $(10,1 \mu \mathrm{g} / \mathrm{mL})$ added to RPMI medium and stained with FITC-conjugated mAb to CD4 and PE-conjugated mAb to GATA-3 or IL-17 (described in Section 2).

hypothesized that HPN and formoterol prevent AHR by downregulating eotaxin and IL-5 expression and, in so doing, by reducing eosinophilia.

A recent study has shown that in a Th2 environment with a dominance of IL-5, a continuous production of eosinophils occurs in a mouse model of allergic inflammation [44]. However, the T cell diversity has been expanded to several subpopulations, including $\mathrm{T}$ helper 17 (Th17) cells, suggesting that the mechanism is more complicated [45]. Interestingly, cotransfer of Th17 cells with Th2 cells enhances the expression of eotaxin-1 in the lung, and the neutralization of eotaxin-1 prior to the inhaled antigen challenge decreases the eosinophil recruitment into the airways of the mice transferred with a combination of Th2 cells and Th17 cells [46]. In our result, the mechanism by which antigen-specific Th17 cells achieve suppression of effector $\mathrm{T}$ cells is not understood. Therefore, our results do not give us information about the functional status of the above cells, that is, Th2 and Th17 cytokine production can differ because of activation status of some cells. Therefore, our result can partly explain the reported inhibition about the Th2 cytokine (IL-5), eotaxin, and IL-17 protein levels. A possible explanation can be that in each specific mechanisms, the one or the other population can predominate and characterize eventually the final result.

Commitment of CD4+ Th cells into effector Th2 cells is controlled by specific transcription factors GATA-binding protein 3 (GATA-3). GATA-3 is required for the direct activation of Th2 cytokines IL-4, IL-5, and IL- 13 for Th2 cell development [47].
Various transcription factors such as c-maf, GATA-3, NFAT, and STAT6 have been shown to induce or augment Th2 cytokine production, although only c-maf and GATA3 are expressed selectively in Th2 cells [48]. In particular, GATA-3 has been shown to promote expression of several Th2 cytokines, including IL-4, IL-5, and IL-13. It is well known that overexpression of GATA-3 predisposes for Th2mediated diseases such as allergic asthma whereas activation of T-bet appears to be an essential step for Th1-mediated mucosal diseases such as Crohns, disease. For instance, suppression of GATA-3 expression in the lung would presumably suppress IL-4, IL-5, and IL-13 production concurrently.

In particular, GATA-3 is important for the expression of IL-5 in T cells by transactivation of the IL- 5 promoter, but GATA-3 only weakly transactivates the IL-4 promoter directly [49].

As shown in Figure 4, the levels of CD4+/GATA3+ double positive cells in $\mathrm{CD} 4+\mathrm{T}$ cells were significantly decreased in HPN treatment group. It can be partly explained that the suppression of GATA-3 expression in the lung would presumably suppress IL-5 production concurrently. However, IL-4 productions in vivo (data not shown) and in vitro was shown different pattern. It is unclear why OVAspecific IFN $-\gamma$ production from spleen T cells (Figure $3(\mathrm{~d})$ ) was enhanced in GATA-3 inhibited condition, but it is possible that an increase in IFN- $y$ alone may not be sufficient for underexpression of GATA-3 and overexpression of T-bet simultaneously. This result appears to be partly due to other signal pathway or more complicated mechanisms involved. 
GATA-3 and T-bet are essential for cytokine gene activation during Th1/Th2 differentiation, but may not be critical factors in Th1 and Th2 cells. The expression of both Tbet and GATA-3 mRNAs decreased in the lungs of mice after repeated antigen challenges. Moreover, the production of Th1/Th2 cytokines in Th1/Th2 cells may not be directly regulated by T-bet or GATA-3, because there is a discrepancy between the expression of T-bet and GATA-3 genes and Th1/Th2 cytokine levels in the lungs of WT mice after repeated antigen challenges [50]. T-bet is regulated by IL12 via STAT4 and by IL-27 via STAT1. This demonstrates the complex interplay of cytokines and transcription factors in asthma [25]. Therefore, our investigation was focused on Th2 cytokines and GATA-3 transcription factor in this paper. Although the precise effects of T-bet and GATA-3 in the pathogenesis of airway remodeling in asthma are still not fully understood, our finding of underexpression of GATA3 in the airways asthma model mice suggests that HPN has a significant inhibitory role in asthma.

Therefore, HPN may reduce Th2 cytokine (IL-5) production and gene expression by inhibition of GATA-3 expression. Our result is not sufficient for the explanation of the precise mechanism, and the mechanism is more complicated. However, it is a possible mechanism that HPN shifts immunity from a Th2 to a Th1 bias in a murine model of asthma. It would be interesting to precisely identify the complicated mechanisms of our results concerning Th1/Th2 transcription factors in future studies. Moreover, additional studies are needed to characterize the precise mechanism of therapeutic action of HPN for treatment of asthma.

\section{Conclusions}

Our data demonstrate that HPN has profound inhibitory effects on airway inflammation in a mouse model of asthma, and this effect was caused by suppression of Th2 cytokines (IL-5), B cell-dependent production of OVA-specific and IgE, eosinophil CCR3 expression, through the inhibition of GATA-3 transcription factor. Hence, HPN may act as a potential Th2 cytokine (IL-5) antagonist and may have a therapeutic effect on allergic asthma.

\section{Acknowledgment}

This paper was supported by Basic Science Research Program through the National Research Foundation of Korea (NRF) funded by the Ministry of Education, Science, and Technology (2010-0007121). S.-H. Kim and Y.-C. Lee contributed equally to this work.

\section{References}

[1] N. A. Barrett and K. F. Austen, "Innate cells and T helper 2 cell immunity in airway inflammation," Immunity, vol. 31, no. 3, pp. 425-437, 2009.

[2] J. Bousquet, P. Chanez, J. Y. Lacoste et al., "Eosinophilic inflammation in asthma," The New England Journal of Medicine, vol. 323, no. 15, pp. 1033-1039, 1990.
[3] H. Nakajima and K. Hirose, "Role of IL-23 and Th17 cells in airway inflammation in asthma," Immune Network, vol. 10, no. 1, pp. 1-4, 2010.

[4] J. Zhu and W. E. Paul, "CD4 T cells: fates, functions, and faults," Blood, vol. 112, no. 5, pp. 1557-1569, 2008.

[5] D. T. Umetsu and R. H. DeKruyff, "TH1 and TH2 CD4+ cells in human allergic diseases," The Journal of Nutrition, vol. 100, no. 1, pp. 1-6, 1997.

[6] M. Wills-Karp, J. Luyimbazi, X. Xu et al., "Interleukin-13: central mediator of allergic asthma," Science, vol. 282, no. 5397, pp. 2258-2261, 1998.

[7] S. Kamaraj, P. Anandakumar, S. Jagan, G. Ramakrishnan, and T. Devaki, "Modulatory effect of hesperidin on benzo(a)pyrene induced experimental lung carcinogenesis with reference to COX-2, MMP-2 and MMP-9," European Journal of Pharmacology, vol. 649, no. 1-3, pp. 320-327, 2010.

[8] J. R. Patil, K. N. Chidambara Murthy, G. K. Jayaprakasha, M. B. Chetti, and B. S. Patil, "Bioactive compounds from mexican lime (Citrus aurantifolia) juice induce apoptosis in human pancreatic cells," Journal of Agricultural and Food Chemistry, vol. 57, no. 22, pp. 10933-10942, 2009.

[9] M. Zielińska-Przyjemska and E. Ignatowicz, "Citrus fruit flavonoids influence on neutrophil apoptosis and oxidative metabolism," Phytotherapy Research, vol. 22, no. 12, pp. 15571562, 2008.

[10] H. J. Park, M. J. Kim, E. Ha, and J. H. Chung, "Apoptotic effect of hesperidin through caspase3 activation in human colon cancer cells, SNU-C4," Phytomedicine, vol. 15, no. 1-2, pp. 147-151, 2008.

[11] M. Yamamoto, A. Suzuki, and T. Hase, "Short-term effects of glucosyl hesperidin and hesperetin on blood pressure and vascular endothelial function in spontaneously hypertensive rats," The Journal of Nutritional Science and Vitaminology, vol. 54, no. 1, pp. 95-98, 2008.

[12] K. Kawaguchi, S. I. Kikuchi, R. Hasunuma, H. Maruyama, T. Yoshikawa, and Y. Kumazawa, "A citrus flavonoid hesperidin suppresses infection-induced endotoxin shock in mice," Biological and Pharmaceutical Bulletin, vol. 27, no. 5, pp. 679-683, 2004.

[13] K. Sakata, Y. Hirose, Z. Qiao, T. Tanaka, and H. Mori, "Inhibition of inducible isoforms of cyclooxygenase and nitric oxide synthase by flavonoid hesperidin in mouse macrophage cell line," Cancer Letters, vol. 199, no. 2, pp. 139-145, 2003.

[14] Y. J. Choi, J. S. Kang, J. H. Y. Park, Y. J. Lee, J. S. Choi, and Y. H. Kang, "Polyphenolic flavonoids differ in their antiapoptotic efficacy in hydrogen peroxide-treated human vascular endothelial cells," The Journal of Nutrition, vol. 133, no. 4, pp. 985-991, 2003.

[15] J. A. Vinson, X. Liang, J. Proch, B. A. Hontz, J. Dancel, and N. Sandone, "Polyphenol antioxidants in citrus juices: in vitro and in vivo studies relevant to heart disease," Advances in Experimental Medicine and Biology, vol. 505, pp. 113-122, 2002.

[16] P. K. Wilmsen, D. S. Spada, and M. Salvador, "Antioxidant activity of the flavonoid hesperidin in chemical and biological systems," Journal of Agricultural and Food Chemistry, vol. 53, no. 12, pp. 4757-4761, 2005.

[17] H. Chiba, M. Uehara, J. Wu et al., "Hesperidin, a citrus flavonoid, inhibits bone loss and decreases serum and hepatic lipids in ovariectomized mice," The Journal of Nutrition, vol. 133, no. 6, pp. 1892-1897, 2003. 
[18] Y. B. Park, K. M. Do, S. H. Bok, M. K. Lee, T. S. Jeong, and M. S. Choi, "Interactive effect of hesperidin and vitamin $\mathrm{E}$ supplements on cholesterol metabolism in high cholesterolfed rats," International Journal for Vitamin and Nutrition Research, vol. 71, no. 1, pp. 36-44, 2001.

[19] H. Tanaka, T. Masuda, S. Tokuoka et al., "The effect of allergen-induced airway inflammation on airway remodeling in a murine model of allergic asthma," Inflammation Research, vol. 50, no. 12, pp. 616-624, 2001.

[20] Y. C. Lee, S. H. Kim, Y. B. Seo, S. S. Roh, and J. C. Lee, "Inhibitory effects of Actinidia polygama extract and cyclosporine A on OVA-induced eosinophilia and bronchial hyperresponsiveness in a murine model of asthma," International Immunopharmacology, vol. 6, no. 4, pp. 703-713, 2006.

[21] G. Cieslewicz, A. Tomkinson, A. Adler et al., "The late, but not early, asthmatic response is dependent on IL-5 and correlates with eosinophil infiltration," The Journal of Clinical Investigation, vol. 104, no. 3, pp. 301-308, 1999.

[22] O. Borges, G. Borchard, A. de Sousa, H. E. Junginger, and A. Cordeiro-da-Silva, "Induction of lymphocytes activated marker CD69 following exposure to chitosan and alginate biopolymers," International Journal of Pharmaceutics, vol. 337, no. 1-2, pp. 254-264, 2007.

[23] M. Y. Lee, K. S. Ahn, OK. K. Kwon et al., "Anti-inflammatory and anti-allergic effects of kefir in a mouse asthma model," Immunobiology, vol. 212, no. 8, pp. 647-654, 2007.

[24] S. S. Roh, S. H. Kim, Y. C. Lee, and Y. B. Seo, "Effects of radix adenophorae and cyclosporine $\mathrm{A}$ on an OVA-induced murine model of asthma by suppressing to $\mathrm{T}$ cells activity, eosinophilia, and bronchial hyperresponsiveness," Mediators of Inflammation, vol. 2008, Article ID 781425, 2008.

[25] P. J. Barnes, "Immunology of asthma and chronic obstructive pulmonary disease," Nature Reviews Immunology, vol. 8, no. 3, pp. 183-192, 2008.

[26] A. Tomkinson, C. Duez, G. Cieslewicz et al., "A murine IL4 receptor antagonist that inhibits IL-4- and IL-13-induced responses prevents antigen-induced airway eosinophilia and airway hyperresponsiveness," Journal of Immunology, vol. 166, no. 9, pp. 5792-5800, 2001.

[27] M. McKinnon, K. Page, I. J. Uings et al., "An interleukin 5 mutant distinguishes between two functional responses in human eosinophils," The Journal of Experimental Medicine, vol. 186, no. 1, pp. 121-129, 1997.

[28] C. J. Sanderson, "Interleukin-5, eosinophils, and disease," Blood, vol. 79, no. 12, pp. 3101-3109, 1992.

[29] J. A. MacLean, R. Ownbey, and A. D. Luster, "T celldependent regulation of eotaxin in antigen-induced pulmonary eosinophila," The Journal of Experimental Medicine, vol. 184, no. 4, pp. 1461-1469, 1996.

[30] S. P. Fernández, C. Wasowski, A. C. Paladini, and M. Marder, "Synergistic interaction between hesperidin, a natural flavonoid, and diazepam," European Journal of Pharmacology, vol. 512, no. 2-3, pp. 189-198, 2005.

[31] G. Kaur, N. Tirkey, and K. Chopra, "Beneficial effect of hesperidin on lipopolysaccharide-induced hepatotoxicity," Toxicology, vol. 226, no. 2-3, pp. 152-160, 2006.

[32] D. Wyss, O. Bonneau, and A. Trifilieff, "Synergistic effect of formoterol and mometasone in a mouse model of allergic lung inflammation," British Journal of Pharmacology, vol. 152, no. 1, pp. 83-90, 2007.

[33] A. Kaplan and D. Ryan, "The role of budesonide/formoterol for maintenance and relief in the management of asthma," Pulmonary Pharmacology and Therapeutics, vol. 23, no. 2, pp. 88-96, 2010.
[34] G. J. Gleich, E. Frigas, and D. A. Loegering, "Cytotoxic properties of the eosinophil major basic protein," Journal of Immunology, vol. 123, no. 6, pp. 2925-2927, 1979.

[35] S. Y. Eum, K. Maghni, Q. Hamid et al., "Inhibition of allergic airways inflammation and airway hyperresponsiveness in mice by dexamethasone: role of eosinophils, IL-5, eotaxin, and IL13," The Journal of Nutrition, vol. 111, no. 5, pp. 1049-1061, 2003.

[36] A. F. Lopez, C. J. Sanderson, J. R. Gamble, H. D. Campbell, I. G. Young, and M. A. Vadas, "Recombinant human interleukin 5 is a selective activator of human eosinophil function," The Journal of Experimental Medicine, vol. 167, no. 1, pp. 219-224, 1988.

[37] C. Feng, K. J. Woodside, B. A. Vance et al., "A potential role for CD69 in thymocyte emigration," International Immunology, vol. 14, no. 6, pp. 535-544, 2002.

[38] M. Kitaura, T. Nakajima, T. Imai et al., "Molecular cloning of human eotaxin, an eosinophil-selective CC chemokine, and identification of a specific eosinophil eotaxin receptor, CC chemokine receptor 3," The Journal of Biological Chemistry, vol. 271, no. 13, pp. 7725-7730, 1996.

[39] S. P. Umland, Y. Wan, J. Shortall et al., "Receptor reserve analysis of the human CCR3 receptor in eosinophils and CCR3-transfected cells," Journal of Leukocyte Biology, vol. 67, no. 3, pp. 441-447, 2000.

[40] M. E. Rothenberg, A. D. Luster, and P. Leder, "Murine eotaxin: an eosinophil chemoattractant inducible in endothelial cells and in interleukin 4-induced tumor suppression," Proceedings of the National Academy of Sciences of the United States of America, vol. 92, no. 19, pp. 8960-8964, 1995.

[41] P. H. S. Sporn, F. P. Fries, and J. A. Anderson, "Eotaxin enhances synthesis of leukotriene C4 synthesis by human blood eosinophils [abstract]," American Journal of Respiratory and Critical Care Medicine, vol. 161, p. A709, 2000.

[42] M. E. Rothenberg, J. A. MacLean, E. Pearlman, A. D. Luster, and P. Leder, "Targeted disruption of the chemokine eotaxin partially reduces antigen- induced tissue eosinophilia," The Journal of Experimental Medicine, vol. 185, no. 4, pp. 785-790, 1997.

[43] J. A. Gonzalo, C. M. Lloyd, L. Kremer et al., "Eosinophil recruitment to the lung in a murine model of allergic inflammation: the role of $\mathrm{T}$ cells, chemokines, and adhesion receptors," The Journal of Clinical Investigation, vol. 98, no. 10, pp. 2332-2345, 1996.

[44] L. L. Zhao, J. Lotvall, A. Linden, M. Tomaki, M. Sjostrand, and A. Bossios, "Prolonged eosinophil production after allergen exposure in IFNgammaR KO mice is IL-5 dependent," Scandinavian Journal of Immunology, vol. 67, pp. 480-488, 2009.

[45] O. Prause, A. Bossios, E. Silverpil et al., "IL-17-producing T lymphocytes in lung tissue and in the bronchoalveolar space after exposure to endotoxin from Escherichia coli in vivoeffects of anti-inflammatory pharmacotherapy," Pulmonary Pharmacology and Therapeutics, vol. 22, no. 3, pp. 199-207, 2009.

[46] H. Wakashin, K. Hirose, Y. Maezawa et al., "IL-23 and Th17 cells enhance Th2-cell-mediated eosinophilic airway inflammation in mice," American Journal of Respiratory and Critical Care Medicine, vol. 178, no. 10, pp. 1023-1032, 2008.

[47] W. Ouyang, S. H. Ranganath, K. Weindel et al., "Inhibition of Th1 development mediated by GATA-3 through an IL-4independent mechanism," Immunity, vol. 9, no. 5, pp. 745755, 1998. 
[48] L. H. Glimcher and K. M. Murphy, "Lineage commitment in the immune system: the T helper lymphocyte grows up," Genes and Development, vol. 14, no. 14, pp. 1693-1711, 2000.

[49] M. F. Neurath, S. Finotto, and L. H. Glimcher, "The role of TH1/TH2 polarization in mucosal immunity," Nature Medicine, vol. 8, no. 6, pp. 567-573, 2002.

[50] T. Kiwamoto, Y. Ishii, Y. Morishima et al., "Transcription factors T-bet and GATA-3 regulate development of airway remodeling," American Journal of Respiratory and Critical Care Medicine, vol. 174, no. 2, pp. 142-151, 2006. 


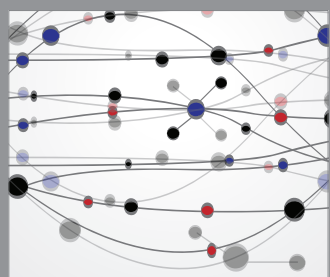

The Scientific World Journal
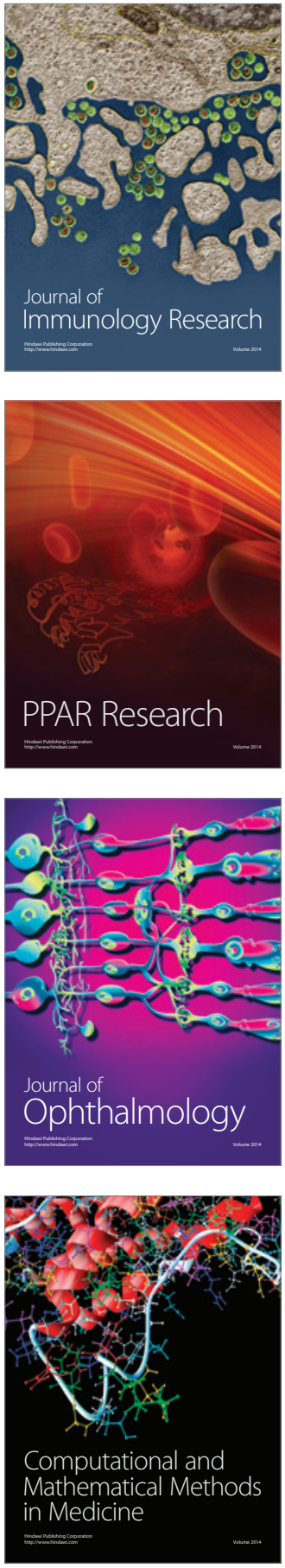

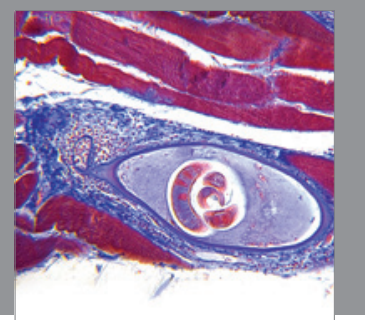

Gastroenterology

Research and Practice
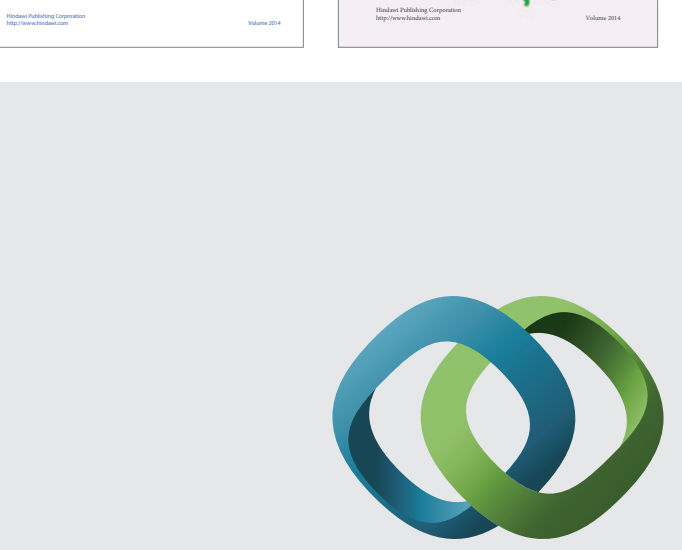

\section{Hindawi}

Submit your manuscripts at

http://www.hindawi.com
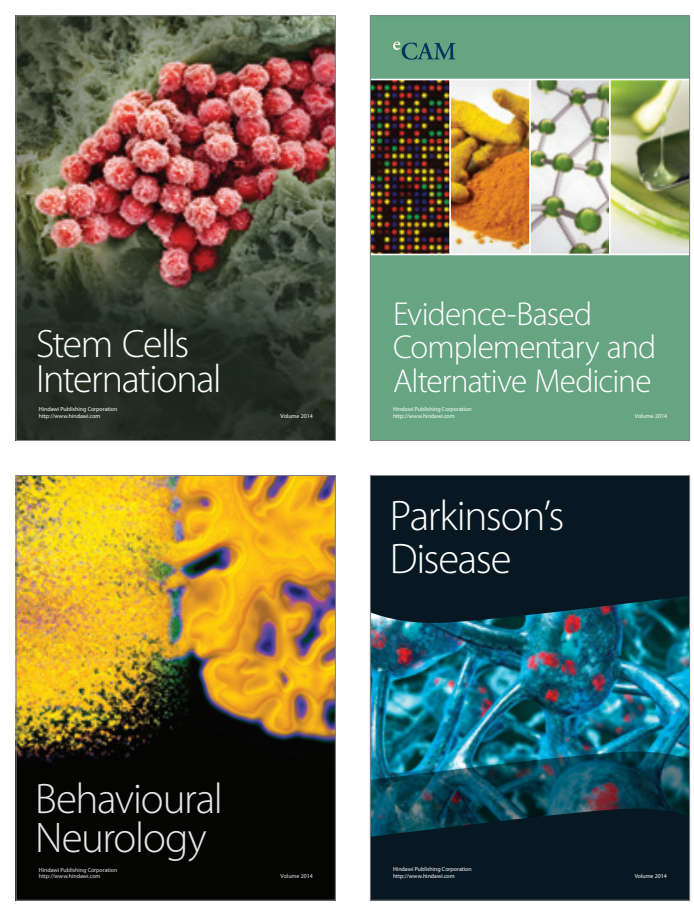

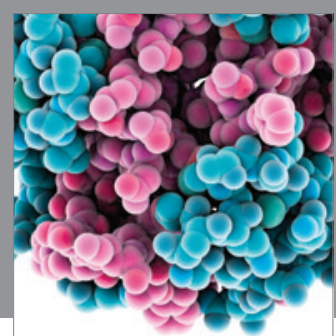

Journal of
Diabetes Research

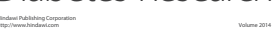

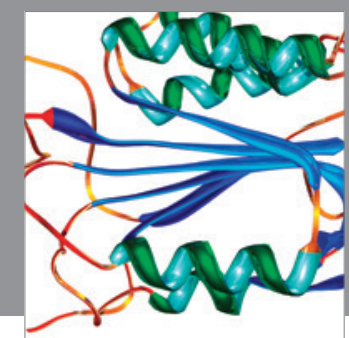

Disease Markers
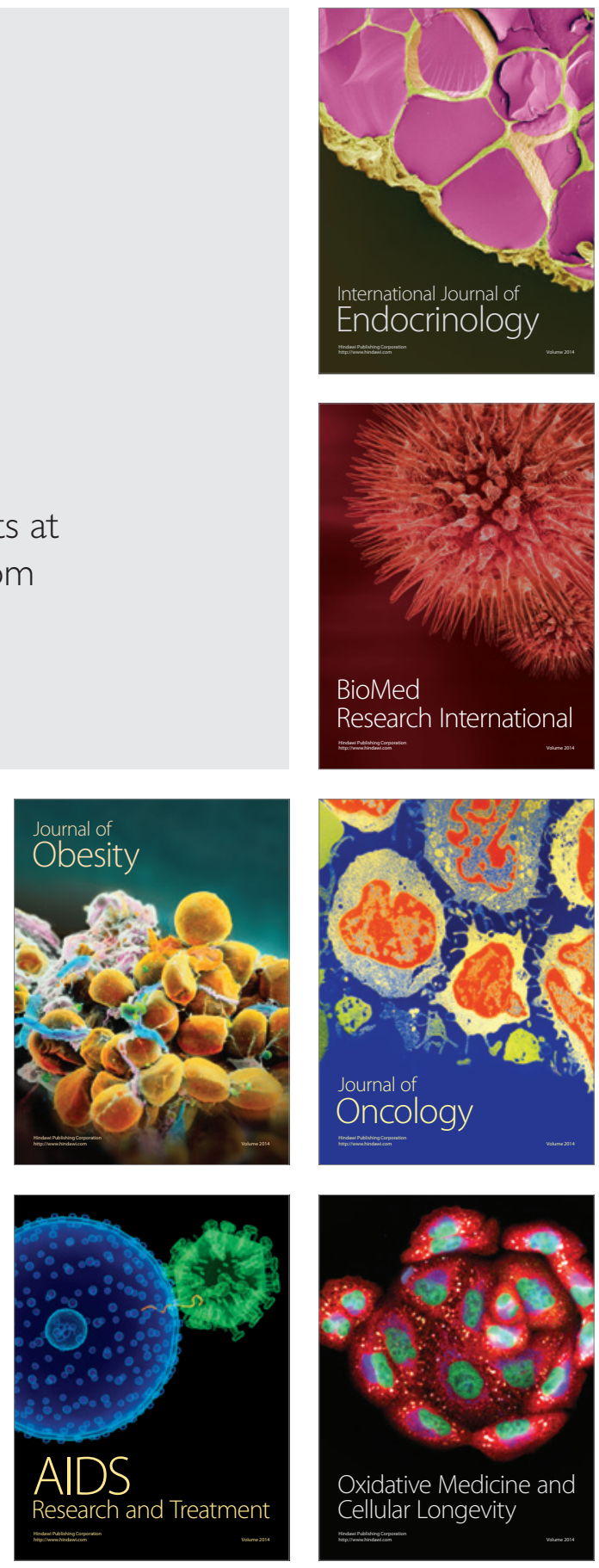